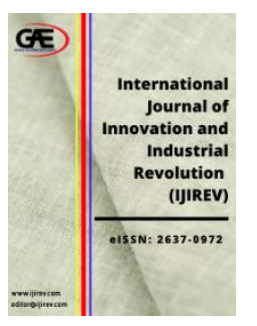

\author{
INTERNATIONAL JOURNAL OF \\ INNOVATION AND \\ INDUSTRIAL REVOLUTION \\ (IJIREV) \\ wWw.ijirev.com
}

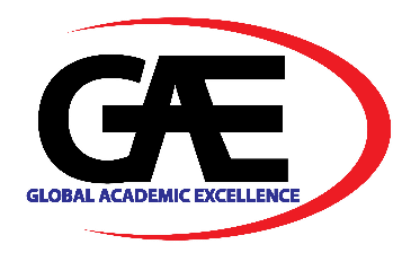

\title{
ENHANCING VITAMIN C CONTENT IN SOAP PRODUCTION VIA SUBSEQUENT AMOUNT OF EXTRACT FROM PHYLLANTHUS AMBLICA AND COSNICIUM BLUEMEANUM
}

\author{
Ruhana Wati $\operatorname{Iran}^{1 *}$, Surina Nordin ${ }^{2}$, Dayang Kamariah Tajul Maulok ${ }^{3}$ \\ 1 Department of Tourism and Hospitality, Politeknik Merlimau, Melaka (PMM), Malaysia \\ Email: ruhana@pmm.edu.my \\ 2 Department of Tourism and Hospitality, Politeknik Merlimau, Melaka (PMM), Malaysia \\ Email: surina@pmm.edu.my \\ 3 Department of Tourism and Hospitality, Politeknik Merlimau, Melaka (PMM), Malaysia \\ Email: dayangkamariah@pmm.edu.my \\ * Corresponding Author
}

\section{Article Info:}

Article history:

Received date: 07.02.2021

Revised date: 24.02 .2021

Accepted date: 04.05.2021

Published date: 15.06.2021

To cite this document:

Iran, R. W., Nordin, S., Maulok, D. K. T. (2021). Enhancing Vitamin C Content In Soap Production Via Subsequent Amount Of Extract From Phyllanthus Amblica And Cosnicium Bluemeanum. International Journal of Innovation and Industrial Revolution, 3 (7), 01-09.

\section{DOI: $10.35631 /$ IJIREV.37001}

This work is licensed under CC BY 4.0

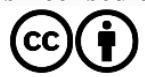

Abstract:

The demand for cosmetic products is rapidly growing, despite the majority of them is high in chemical substances and may harm the skin. Nowadays, there are other alternatives that may help to prevent the use of chemical substances in cosmetic products. For example, fruit contains its own nutrient. Furthermore, there are some fruits that contains high in vitamins and also good for the skin. Researchers noticed that Phyllantus amblica (Melaka fruits) has an unpleasant odor but it higher with contains 30 times more vitamin $\mathrm{C}$ compared to orange while Cosnicium blumeanem (mengkunyit) helps raise the level of vitamins $C$ in the body. Therefore, looking at potential and benefits, research has been conducted to produce a bar soap (Amblica Soap) from Phyllantus amblica and Cosnicium blumeanem. Analyze has been done to determine the vitamin C, antioxidant level, and perception level of respondents towards Amblica Soap. Likert Scale and High-Performance Liquid Chromatography (HPLC) was used as the quantitative instrument. A number of 30 respondents were selected based on their locality. Descriptive analysis was used to analyses collected using SPSS version 25.0. Resulting confirming that is Amblica Soap not contain in vitamin $\mathrm{C}$ and shows the perception level of respondents towards Amblica Soap is highly positive. In conclusion, Amblica Soap accepted optimistically.

Keywords:

Phyllantus Amblica, Cosnicium Blumeanem, Vitamin C 


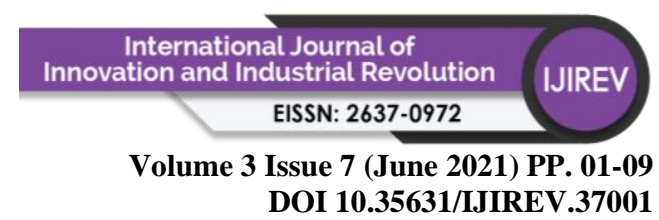

\section{Introduction}

The cosmetic industry is dominated by a small number of multinational corporations that originated in the early 20th century, but the distribution and sale of cosmetic is spread among a wide range of different businesses. Even though the demand of cosmetic products is rapidly growing, despite majority of the cosmetic product is high in chemical substances and may harm the skin (Moyad, 2017).

Nowadays, there are other alternatives that may help to prevent the use of chemical substances in cosmetic products. For example fruits contain their own nutrient. Furthermore, there are some fruits that contains high in vitamins and also good for skin. The goodness of the fruits may help to get rid of the uses of chemical substances and may provide the good chance to spread the natural substances in cosmetic products. Thus, vitamin $\mathrm{C}$ is also good for skin. Based on research, Melaka fruit contains more than 30 times vitamin $\mathrm{C}$ compared to oranges. Therefore, Melaka fruit also can be innovated into soap (Moyad, 2017).

In Malaysia, the Melaka tree is planted for landscaping purposes. This happens because the locals did not know that Phyllanthus amblica (Melaka fruit) contains a lot of vitamin $\mathrm{C}$ and has benefits to health (Singh et.al, 2011). This fruit contains $720 \mathrm{mg}$ vitamin $\mathrm{C}$ in every $100 \mathrm{~g}$ fresh Melaka fruit (Singh et.al, 2011) and has antioxidant value. Vitamin C content in fruits as Table 1.

Table I: Vitamin C Content in Fruits

\begin{tabular}{lc}
\hline \multicolumn{1}{c}{ Fruit } & Vitamin C (mg/100g) \\
\hline Melaka fruit & 700 \\
Guava & 100 \\
Kiwi & 90 \\
Lychee & 70 \\
Starberry & 60 \\
Papaya & 60 \\
Orange & 50 \\
Lemon & 40 \\
Mango & 28 \\
Honeydew & 20 \\
Grape & 10 \\
Apricot & 10 \\
Banana & 9 \\
Avocado & 8 \\
Apple & 6 \\
Pear & 4 \\
\hline
\end{tabular}

(Ehrlich, 2011 and Gloryfrench, 2006)

Looking for its potential and benefit, a research has been conducted to produce a bar soap named Amblica Soap from Phyllantus amblica (Melaka fruit) and Cosnicium blumeanem (mengkunyit). Other than that, researcher want to determine the vitamin $\mathrm{C}$ content and also to know the level of acceptance toward Amblica Soap. 


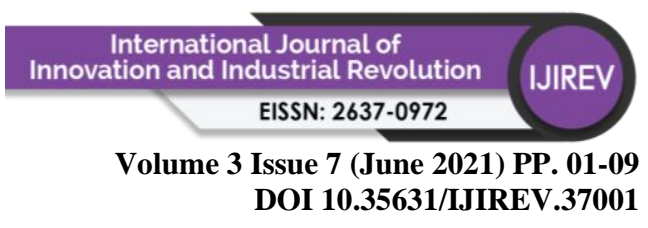

\section{Literature Review}

\section{Phyllantus Amblica (Melaka Fruit)}

Aging problem is common with the increase in age. But the process of aging is totally changed. Skin starts to show sign of aging at an early age. These early signs of aging are due to unhealthy diet, pollution, stress and much more. Luckily, Melaka fruit helps to fight the problem of aging due to its high antioxidants content. Oxidative Radiance Activity Capacity (ORAC) value is 3387 micromole per $100 \mathrm{~g}$. Free radicals are known to damage healthy cells. They damage the healthy skin and accelerate the process of aging. But antioxidants fight these free radicals and slow down the process of aging. (Moyad, 2017).

Malacca fruit is very rich in Vitamin C, and contains many minerals and vitamins like Calcium, Phosphorus, Iron, Carotene and Vitamin B Complex. Many health problems are caused by oxidative damage (when body cells use oxygen, they produce by-products called free radicals that can cause damage). Antioxidant agents prevent and repair these damages. Vitamin $\mathrm{C}$ is a good antioxidant agent, which makes gooseberries a powerful tool against a variety of conditions, including various types of cancer. ( Harshanjit Singh,2002)

For many years the therapeutic potential of the fruits was attributed to their high ascorbic acid content, about $1 \mathrm{~g}$ Vitamin C per 100ml of fresh juice (P. Scartezzini, 2006). Its fruit is reported to probably have the highest content of Vitamin $\mathrm{C}$ compared with any other naturally occurring substances in nature (Pornpimon MayaChiew, 2008).

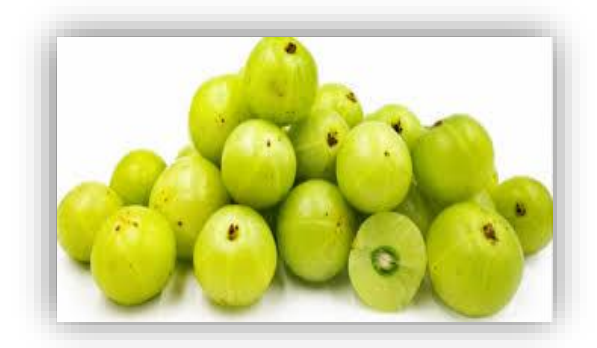

Picture 1: Phyllantus Amblica (Melaka Fruit)

\section{Coscinium Blumeanum (Mengkunyit)}

Coscinium blumeanum (mengkunyit) used as an effective sinus medication in Malay traditional medicine. This herb can relieve itching on the face, scalp and nose, frequent sneezing and a runny nose, acne on the face, itching in the toenails and hands. It also contains an antibiotic effect against some types of bacteria and fungi. The high content of flavonoids in the plant causes the function to act as anti-oxidants that can produce substances histamine and other allergies. Another advantage of this herb is to help raise levels of vitamin $\mathrm{C}$ in the body that protect against free radical damage and strengthens the joints. (datatanamanherba, 2011) 


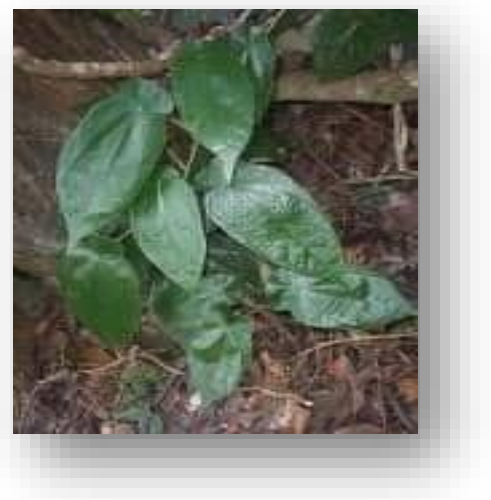

\section{Picture 2: Coscinium blumeanum (mengkunyit)}

Coscinium blumeanum ( mengkunyit) is a wild plant that is commonly found in the forest, it is a climbing plant that can grow up to a height of ten feet (to climb on other plants or support) leaf width and length measures $7 \times 20 \mathrm{~cm}$. There are two types of Coscinium blumeanum (mengkunyit) that are mengkunyit gold and mengkunyit silver in contrast to the color of leaves. (datatanamanherba, 2011)

\section{Glycerin}

Glycerine is a humectant. It absorbs water from the air and thus attracts moisture to the skin. Glycerine is a natural by-product of the soap making process (chargrinvalleysoapandslave, 2017). Glycerine is an organic compound composed of carbon, oxygen and hydrogen (Axe, 2017). This thick, colourless and odourless liquid is used extensively in the beauty industry for making soap, antiaging gels and moisturizers. It was first discovered in 1779 by Swedish chemist, Karl Wihelm Scheele, who named it "sweet principle of fat" in 1811, Michel Chevreul's, a Frenchman, named it glycerine, which comes from the Greek word glyks meaning sweet. Glycerine was mainly utilized for medical used and personal care until the late 1800's (chargrinvalleysoapandsalve, 2017). As a humectant, this ingredient is often found as an ingredient in cosmetic products such as face washes, skin cream and lotion, soap and mouth washes.

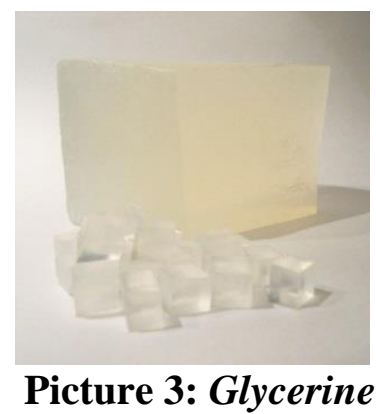

\section{Peppermint Oil Essence}

Pleasantly suitable for an abundance of oral and topical uses and antimicrobial properties, peppermint may be the most versatile essential oil in the world along with lavender. Literally, there are few body, health and mind issues that it cannot help. Peppermint essential oil gives a cooling sensation and has a calming effect on the body, which can relieve sore muscles when used topically. It also has antimicrobial properties so it can help freshen bad breath and soothe 
digestive issues. Clinically speaking, peppermint oil is recommended for its anti-nausea benefits and soothing effects on the gastric lining and colon because of its ability to reduce muscle spasms. Not only is peppermint one of the oldest European herbs used for medical purposes, other historical accounts date its used to ancient Chinese and Japanese folk medicine. Peppermint oil benefit soothe digestive issues, relieves headache, improve mental focus, boosts energy, releases tight muscle, sinus care, allergy relief, skin health, acne treatment and sunburn relief.(Axe,2017)

\section{Research Methodology}

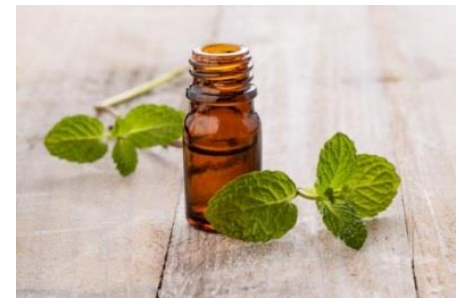

Picture 4: Peppermint Oil Essence

\section{Producing Amblica Soap}

There are four main ingredients required in the production of Amblica Soap. They are extraction of Melaka fruit and also mengkunyit, glycerin, and peppermint essential oil. These then put it into a soap mold with room temperature to harden and become a soap bar. The process flow of producing the Amblica Soap is illustrated as in Figure 1.

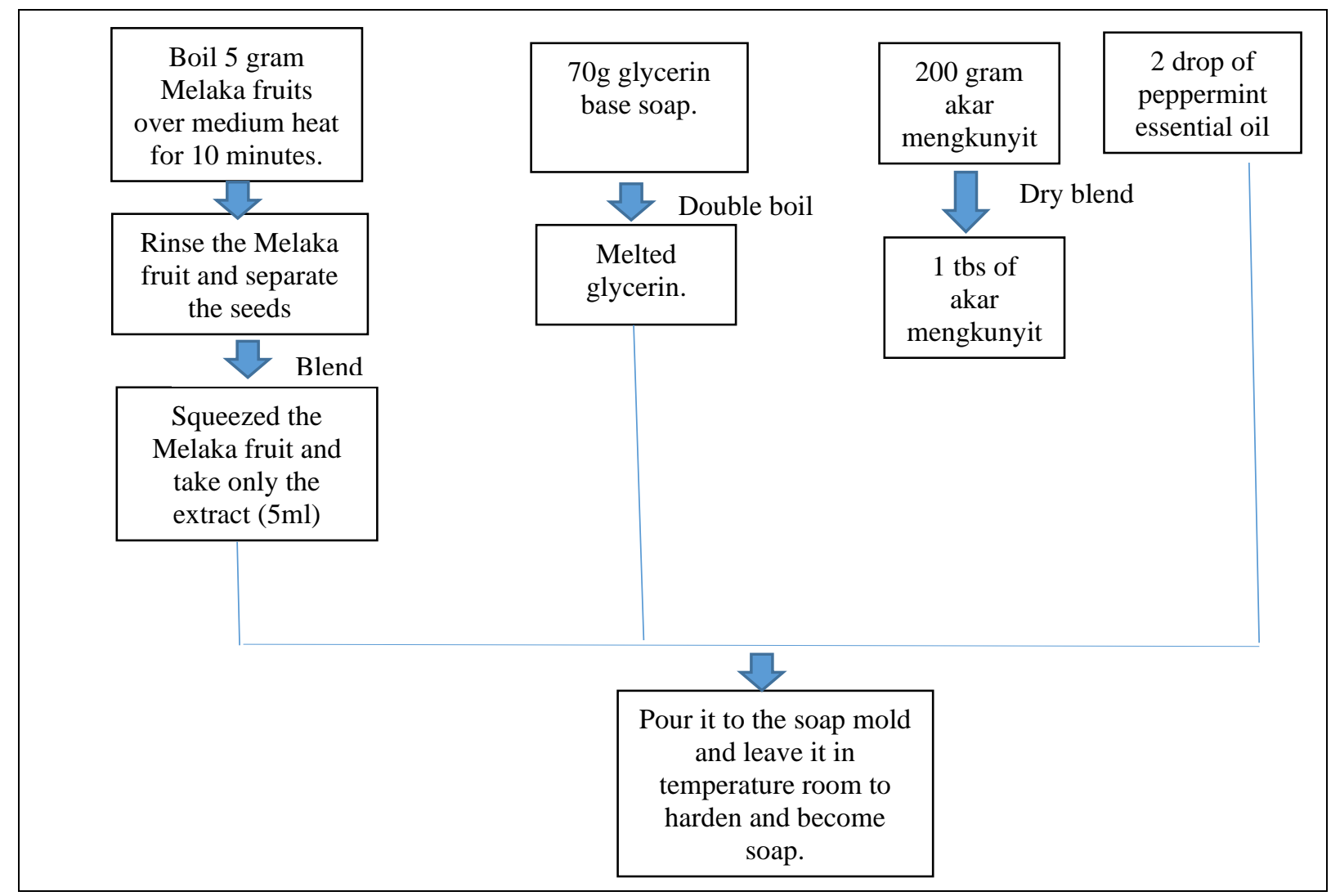

Figure 1: Process of Making Amblica Soap 


\section{Research Design}

Researchers has used quantitative research design. A set of questionnaire using Likert Scale was used to determine the acceptance level of respondents towards Amblica Soap as in Figure 2.

\begin{tabular}{|l|c|c|c|c|c|}
\hline \multicolumn{1}{|c|}{ Item Evaluated } & $\begin{array}{c}\text { Very } \\
\text { Dislike } \\
(\mathbf{1})\end{array}$ & $\begin{array}{c}\text { Dislike } \\
\mathbf{( 2 )}\end{array}$ & $\begin{array}{c}\text { Not sure } \\
(\mathbf{3})\end{array}$ & $\begin{array}{c}\text { Like } \\
\mathbf{( 4 )}\end{array}$ & $\begin{array}{c}\text { Really } \\
\text { Like } \\
\text { (5) }\end{array}$ \\
\hline I like the colour of soap & & & & & \\
\hline I like the texture of this soap & & & & & \\
\hline I like the smell of this soap & & & & & \\
\hline The soap is not slimy & & & & & \\
\hline $\begin{array}{l}\text { This soap makes my skin } \\
\text { softer }\end{array}$ & & & & & \\
\hline
\end{tabular}

Figure 2: Questionnaire to Determine Respondent Acceptance Level towards Amblica Soap

Research was done to determine respondent acceptance level towards Amblica Soap which are its colour, texture, smell, in term of the soap is not slimy and skin smoothness, moistness, fairness after application.

\section{Research Respondent}

Respondent from ages from 18 to 50 years old were selected. This is because aging problem is common with the increase in age. Skin starts to show sign of aging at an early age. These early signs of aging are due to unhealthy diet, pollution, stress and much more (Harshanjitsingh, 2002). 30 respondents were given Amblica Soap sample. They applied the sample onto the skin prior answering the questionnaires.

\section{Vitamin C Analysis}

The High Performance Liquid Chromatography (HPLC) at the Department of Chemistry Malaysia, Ministry of Science, Technology and Innovation was used to determine the amount of Vitamin $\mathrm{C}$, while $\mathrm{pH}$ value was determined using the $\mathrm{pH}$ meter.

\section{Data Analysis Method}

Data collected from the questionnaires were analysed using Statistical Package for Social Science (SPSS) version 25.0 and interpreted using mean score. The mean value range interpretation are in Table 2.

Table 2: Interpretations of the Range Of Value Mean

\begin{tabular}{lcc}
\hline Score Mean & Interpretation & Level \\
\hline 1.00 to 2.33 & Low & Weak \\
2.34 to 3.66 & Middle & Middle \\
3.67 to 5.00 & High & Good \\
\hline
\end{tabular}




\section{Data Analysis}

\section{Producing a Soap Bar by Using Extract from Melaka Fruit and Mengkunyit}

Analysis showed that the respondents highly accepted the Amblica Soap after application with mean value 4.00. Table 3 indicates the mean score for attribute evaluated.

Table 3: Interpretations of Mean Score of Amblica Soap

\begin{tabular}{lccc}
\hline Item Evaluated & Score Mean & Interpretation & Level \\
\hline Acceptance & 4.00 & High & Good \\
\hline
\end{tabular}

\section{To Determined Vitamin C Content in Amblica Soap}

Result indicated that the $\mathrm{pH}$ value is 9.5. It is also confirmed that vitamin $\mathrm{C}$ is not detected in Amblica Soap with amount of ND $<0.1$ as indicated in Table 4.

Table 4: Interpretations of Vitamin C Content in Amblica Soap

\begin{tabular}{lccc}
\hline Test Parameter & Test Method & Unit & Result \\
\hline $\mathrm{pH}$ & $\mathrm{pH}$ meter & - & 9.5 \\
Vitamin C & HPLC & $\mathrm{mg} / 100 \mathrm{~g}$ & $\mathrm{ND}<0.1$ \\
\hline
\end{tabular}

(Malacca Institute of Biotechnology, 2012)

\section{To Determine the Perception Level of Acceptance towards Amblica Soap}

Respondents moderately agree that the color of Amblica Soap with mean value 3.47, the pleasurably texture and refreshing smell is strongly accepted with mean value 3.80 and 4.37 respectively. They also strongly agree that Amblica Soap possess good slimmy giving mean score 3.67, and also Amblica Soap giving them soft skin with mean value 4.10. Table 4 indicates the mean score for each attribute evaluated.

\begin{tabular}{lccc} 
Table 5: Interpretations of perception Level of Amblica Soap \\
\hline Item Evaluated & Score Mean & Interpretation & Level \\
\hline Color & 3.47 & Middle & Middle \\
Texture & 3.80 & High & Good \\
Smell & 4.37 & High & Good \\
Slimy & 3.67 & High & Good \\
Soft skin & 4.10 & High & Good \\
\hline
\end{tabular}

\section{Results and Discussion}

Overall, respondent's acceptance of this product is high. Nutritional analysis showed that the Amblica Soap is not contains in vitamin C. The majority of people who consumed Amblica Soap like the soap very much and smells fragrant and fresh.

Each of which types of fruit has its own privileges, as well as the fruit of Malacca. The results of the study, many who still do not know what the Melaka fruit, efficacy and benefits.

Malacca fruit is very rich in vitamin $\mathrm{C}$, and contains many minerals and vitamins like Calcium, Phosphorus, Iron, Carotene and Vitamin B Complex. Many health problems are caused by oxidative damage (when body cells use oxygen, they produce by-products called free radicals 


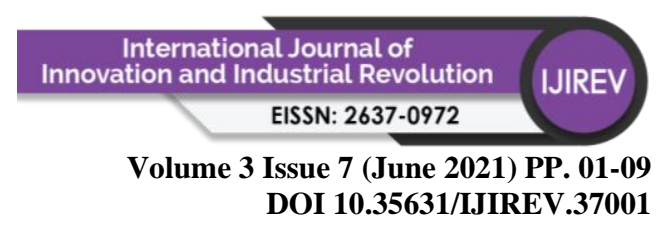

that can cause damage). Antioxidant agents prevent and repair these damages. VitaminC is a good antioxidant agent, which makes gooseberries a powerful tool against a variety of conditions, including various types of cancer. (Harshanjit singh, 2002).It is also stated that by The Melaka Fruit is rich in Vitamin C (Lim T.K,2012)

Mengkunyit also have properties to help problem sinus and have high nutrition. Coscinium Blumeanum (Mengkunyit) used as an effective sinus medication in Malay traditional medicine. This herb can relieve itching on the face, scalp and nose, frequent sneezing and a runny nose, acne on the face, itching in the toenails and hands. It also contains an antibiotic effect against some types of bacteria and fungi. The high content of flavonoids in the plant causes the function to act as anti-oxidants that can produce substances histemin and other allergies. Another advantage of this herb is to help raise levels of vitamin $C$ in the body that protect against free radical damage and strengthens the joints. (datatanamanherba,2011)

In this research also, it is proven that the Amblica Soap is not contain in vitamin $\mathrm{C}$ reported by Melaka Biotechnology Corporation and the acceptance level for Amblica Soap is 4.00 which is high and in a good level of acceptance of Amblica Soap.

\section{Recommendation}

For recommendation, researcher suggested that the Amblica fruit and mengkunyit is added after the Glycerin base soap cool down. It is for enhance the more vitamin C in the Amblica Soap.

\section{Summary}

In conclusion, the results of the discussions can be concluded that the Amblica Soap is highly accepted.

\section{References}

Caldecott, Todd (2006). Retrieved from https://www.toddcaldecott.com/herbs/learningherbs/397-amalaki

D'Alexa (2017). Retrieved from https://pageadviser.com/www.chagrinvalleysoapandsalve.com.html

Ehrlich, D. S. Vitamin C. (2011), unpublished

Gloryfrench. Fruits nutritioanal contents. in press (2006). Retrieved from http://www.indoforum.org/T17276/

Benefit of Glycerin in skincare. Retrieved from https://www.paulaschoice.com/expertadvice/skincare-advice/ingredient-spotlight/benefits-glycerin-skincare.html

Shampoo Bars. Retrieved from https://www.chagrinvalleysoapandsalve.com/products/naturalhair/natural-shampoo-bars!

Indian food forever (2008) 100gm of this fruit contains $700 \mathrm{mg}$ of vitamin C, Wonderful Amlafruit , Retrieved from http://www.Indianfoodforever.com/foodguide/WonderfulAmla.Html

Josh axe (2017). Retrieved from https://draxe.com/

Lim, T.K. (2012). "Phyllanthus emblica". Edible Medicinal and Non-Medicinal Plants. Retrieved from https://link.springer.com/chapter/10.1007/978-94-007-40532_37\#page-1

Mark Moyad (2017). Retrieved from http://www.webmd.com/diet/features/the-benefits-ofvitamin-c 
Purdiawan pur (2011) Retrieved from https://datatanamanherba.blogspot.my/2011/07/akarmengkunyit.html

Puri, Harsharnjit Singh (2002). "Amalaki (Phyllanthus emblica)". Rasayana: Ayurvedic Herbs for Longevity and Rejuvenation. Traditional Herbal Medicines for Modern Times Retrieved from http://www.shadowsgovernment.com/shadowslibrary/Rasayana\%20Ayurvedic\%20Herbs\%20for\%20Longevity\%20and\%20Rejuven ation.pdf

Pornpimon M, Sakamon D. Antimicrobial and antioxidant activities of Indian gooseberry and galangal extracts. LWT 41 (2008) .

Mohd Najib Abd Ghafar, (2003), Rekabentuk Soal Selidik Pendidikan, Universiti Teknology Malaysia. ISBN :9835203105, 9789835203107

Singh E., Sharma S., Pareek A., Dwivedi J., Yadav S., Sharma S. (2011). Phytochemistry, traditional uses and cancer chemopreventive activity of Amla (Phyllanthus emblica): The Sustainer. Journal of Applied Pharmaceutical Scienc 